\title{
ВПРОВАДЖЕННЯ МЕТОДУ СТЕНТУВАННЯ КОРОНАРНИХ АРТЕРІЙ В УКРAÏHI
}

ДВНЗ «Тернопільський державний медичний університет імені І.Я. Горбачевського МОЗ України», м. Тернопіль, Україна

Мета - аналіз запровадження методу стентування коронарних артерій (СКА) в лікуванні пацієнтів 3 ішемічною хворобою серця в Україні та її областях.

Матеріали і методи. Матеріалом дослідження слугували дані дЗ «Центр медичної статистики МОЗ України» про кількість оперативних втручань на серці та проведених операцій СКА в Україні. У роботі використано метод системного аналізу та статистичний метод дослідження.

Результати. Отримані дані свідчать про істотне зростання як рівня оперативних втручань 3 приводу СКА за період 2013-2015 рр. на 28,1\%, так і його частки серед усіх операцій на серці. Найвищий рівень оперативних втручань 3 приводу СКА у 2015 р. спостерігався у м. Києві, Черкаській, Закарпатській та Рівненській областях. Найнижчий у Житомирській, Чернівецькій та Запорізькій областях. Найбільше зростання післяопераційної летальності в 2015 р. порівняно із 2013-2014 рр. спостерігалося в Одеській, Кіровоградській та Полтавській областях. Деяке зменшення післяопераційної летальності відмічалося у Київській, Волинській, Львівській областях.

Висновки. За період 2013-2015рр. в Україні відбулося активне впровадження інтервенційного методу лікування пацієнтів з інфрарктом міокарда та нестабільною стенокардією.

КЛЮчОВІ СЛОВА: стентування коронарних артерій, операції на серці, інфаркт міокарда, рівень оперативних втручань, післяопераційна летальність.

Інтервенційні методи лікування інфраркту міокарда (IM) та нестабільної стенокардії останніми роками набувають все більшого поширення. Основними методиками, які використовуються при цих захворюваннях, $€$ аортокоронарне шунтування (АКШ) та стентування коронарних артерій (СКА). В останніх дослідженнях багато авторів вказують на значні переваги методу СКА над АКШ [1-3;7-9].

Мета дослідження - аналіз запровадження методу СКА в лікуванні пацієнтів з ішемічною хворобою серця в Україні та її областях.

Матеріали і методи. Матеріалом дослідження слугували дані Д3 «Центр медичної статистики МО3 України» про кількість оперативних втручань на серці та проведених операцій СКА в Україні [4-6]. У роботі використано метод системного аналізу та статистичний метод дослідження.
Результати дослідження та їх обговорення. Перкутанні коронарні втручання почали застосовувати в Україні на початку 21-го століття. Нами проведено аналіз цих втручань за 2013-2015 роки.

Так, загальна кількість оперативних втручань на серці за цей період зменшилася на 6,6\%, але рівень оперативних втручань зменшився лише на 0,8\%. Проте при зменшенні хірургічної активності зросла післяопераційна летальність за цей період на 13,4\% (табл. 1).

При аналізі операцій з приводу СКА виявлено, що їх кількість за досліджуваний період зросла на 20,5\%, а рівень оперативних втручань 3 приводу СКА - на 28,1\%. Також зросла і післяопераційна летальність - на 95,3\% (табл. 2).

Частка пацієнтів, яким проводили СКА, щодо загальної кількості операцій на серці поступово

Таблиця 1. Операції на серці, проведені в Україні за період 2013-2015 рр.

\begin{tabular}{|l|c|c|c|c|}
\hline Рік & $\begin{array}{c}\text { Загальна кількість } \\
\text { операцій }\end{array}$ & $\begin{array}{c}\text { На 10 тис. усього } \\
\text { населення }\end{array}$ & $\begin{array}{c}\text { Кількість померлих у } \\
\text { результаті операцій }\end{array}$ & $\begin{array}{c}\text { Післяопераційна } \\
\text { летальність } \\
\text { (\%) }\end{array}$ \\
\hline 2013 & 28051 & 6,18 & 419 & 1,49 \\
\hline $2014^{*}$ & 23682 & 5,52 & 360 & 1,52 \\
\hline $2015^{*}$ & 26199 & 6,13 & 443 & 1,69 \\
\hline
\end{tabular}

*Примітка. Статистичні дані не враховують показник з тимчасово окупованої території Автономної Республіки Крим, Донецької і Луганської областей.

(c) Н.О. Теренда, 2016 
Таблиця 2. Оперативні втручання з приводу стентування коронарних артерій, проведені в Україні за період 2013-2015 рр.

\begin{tabular}{|c|c|c|c|c|}
\hline Рік & $\begin{array}{c}\text { Загальна кількість } \\
\text { операцій }\end{array}$ & $\begin{array}{c}\text { На 10 тис. усього } \\
\text { населення }\end{array}$ & $\begin{array}{c}\text { Кількість померлих у } \\
\text { результаті операцій }\end{array}$ & $\begin{array}{c}\text { Післяопераційна } \\
\text { летальність (\%) }\end{array}$ \\
\hline 2013 & 6956 & 1,53 & 59 & 0,85 \\
\hline $2014^{\star}$ & 6801 & 1,59 & 81 & 1,19 \\
\hline $2015^{*}$ & 8383 & 1,96 & 139 & 1,66 \\
\hline
\end{tabular}

*Примітка. Статистичні дані не враховують показник з тимчасово окупованої території Автономної Республіки Крим, Донецької і Луганської областей.

зростає. Так, у 2013 р. вона становила 24,8\%, у 2014 р. $-28,7 \%$, а у 2015 р. - 32,0\% (рис.).

При поглибленому аналізі окремих областей України виявлено, що найбільше оперативних втручань на серці було проведено у м. Києві, Дніпропет- ровській, Львівській, Одеській, Херсонській областях. Післяопераційна летальність була найвищою у Запорізькій, Кіровоградській, Чернігівській та Вінницькій областях (табл. 3).

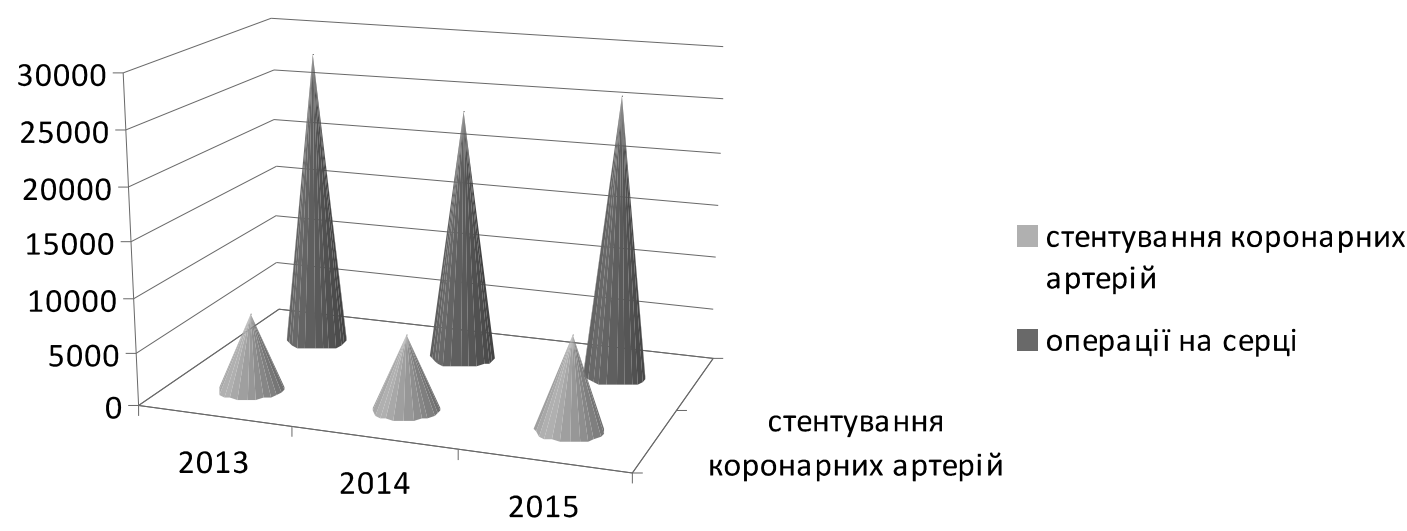

Рис. Співвідношення оперативних втручань на серці та стентування коронарних артерій в Україні за період 2013-2015 рр.

Відмічається тенденція до зростання загальної кількості оперативних втручань з приводу СКА за період 2013-2015 років в окремих областях України. Безумовним лідером щодо кількості та рівня проведених оперативних втручань з приводу СКА є м. Київ (відповідно 1886 проведених операцій, або 6,63 на 10 тис. населення). Найбільше зростання кількості СКА спостерігається у Волинській $(287,5 \%)$, Київській $(209,4 \%)$, Харківській $(196,9 \%)$ областях. У Закарпатській та Чернівецькій областях СКА було проведено вперше у 2015 р. і становило відповідно 549 і 67 операцій. У Сумській області оперативних втручань на коронарних судинах взагалі не проводили. У деяких областях України спостерігається зменшення операцій СКА: у Запорізькій - 55,2\%, Дніпропетровській - 74,7\%, Миколаївській - 86,6\%.

Рівень оперативних втручань 3 приводу СКА по областях у 2015 р. був найвищим у Черкаській (4,64 на 10 тис. населення), Закарпатській (4,37 на 10 тис. населення), Рівненській (3,74 на 10 тис. населення) областях. Найнижчий рівень спостерігався у Житомирській (0,56 на 10 тис. населення), Чернівецькій (0,74 на 10 тис. населення) та Запорізькій (0,72 на 10 тис. населення) областях. Якщо низький рівень оперативних втручань у Чернівецькій області пов'язаний із тим, що там лише у 2015 р. розпочали проводити СКА, то необхідно відмітити значний прогрес у Закарпатській області, де також у 2015 р. розпочали проводити такі операції, але із розрахунку на 10 тис. населення вона займає провідні місця (табл. 4).

Післяопераційна летальність після проведених операцій СКА у 2015 р. була найвищою в Одеській (5,6\%), Кіровоградській $(4,67 \%)$ та Чернігівській $(4,01 \%)$ областях. Найменший показник спостерігався у Волинській $(0,43 \%)$, Львівській $(0,49 \%)$ областях та м. Києві $(0,48 \%)$. Найбільше зростання післяопераційної летальності порівняно із 20132014 рр. спостерігалося в Одеській (у 4,5 разу), Кіровоградській $(3,9)$ та Полтавській $(3,8)$ областях. Зменшення післяопераційної летальності відмічалося у Київській (на 70,7\%), Волинській (65,6\%), Львівській (62,9\%) областях (табл. 5). 
Таблиця 3. Операції на серці, проведені в регіонах України за період 2013-2015 рр.

\begin{tabular}{|c|c|c|c|c|c|c|c|c|c|c|c|c|c|}
\hline \multirow[t]{2}{*}{$\begin{array}{l}\text { № } \\
\text { 3/ח }\end{array}$} & \multirow[t]{2}{*}{ Регіон } & \multicolumn{3}{|c|}{$\begin{array}{c}\text { Загальна кількість } \\
\text { операцій }\end{array}$} & \multicolumn{3}{|c|}{$\begin{array}{c}\text { На } 10 \text { тис. усього } \\
\text { населення }\end{array}$} & \multicolumn{3}{|c|}{$\begin{array}{c}\text { Кількість померлих } \\
\text { в результаті } \\
\text { операцій }\end{array}$} & \multicolumn{3}{|c|}{$\begin{array}{c}\text { Післяопераційна } \\
\text { летальність (\%) }\end{array}$} \\
\hline & & 2013 & 2014 & 2015 & 2013 & 2014 & 2015 & 2013 & 2014 & 2015 & 2013 & 2014 & 2015 \\
\hline 1 & $\begin{array}{l}\text { Автономна } \\
\text { Республіка Крим }\end{array}$ & 2087 & 0 & 0 & 10,67 & 0,00 & 0,00 & 10 & 0 & 0 & 0,48 & 0,00 & 0,00 \\
\hline 2 & Вінницька & 546 & 669 & 701 & 3,37 & 4,15 & 4,37 & 8 & 17 & 22 & 1,47 & 2,54 & 3,14 \\
\hline 3 & Волинська & 1114 & 481 & 530 & 10,74 & 4,63 & 5,10 & 3 & 2 & 5 & 0,27 & 0,42 & 0,94 \\
\hline 4 & Дніпропетровська & 4197 & 4004 & 3655 & 12,70 & 12,17 & 11,17 & 47 & 51 & 49 & 1,12 & 1,27 & 1,34 \\
\hline 5 & Донецька & 1228 & 8 & 2 & 2,81 & 0,02 & 0,01 & 20 & 1 & 0 & 1,63 & 138 & 0,00 \\
\hline 6 & Житомирська & 176 & 159 & 191 & 1,39 & 1,26 & 1,52 & 2 & 2 & 5 & 1,14 & 1,26 & 2,62 \\
\hline 7 & Закарпатська & 296 & 288 & 780 & 2,37 & 2,30 & 6,21 & 8 & 8 & 12 & 2,70 & 2,78 & 1,54 \\
\hline 8 & Запорізька & 611 & 709 & 513 & 3,42 & 3,99 & 2,91 & 15 & 17 & 17 & 2,45 & 2,40 & 3,31 \\
\hline 9 & Івано-Франківська & 462 & 512 & 457 & 3,35 & 3,71 & 3,31 & 6 & 15 & 13 & 1,30 & 2,93 & 2,84 \\
\hline 10 & Київська & 107 & 231 & 373 & 0,62 & 1,34 & 2,16 & 5 & 3 & 4 & 4,67 & 1,30 & 1,07 \\
\hline 11 & Кіровоградська & 205 & 193 & 212 & 2,07 & 1,97 & 2,18 & 2 & 3 & 8 & 0,98 & 1,55 & 3,77 \\
\hline 12 & Луганська & 1573 & 0 & 2 & 6,99 & 0,00 & 0,03 & 37 & 0 & 1 & 2,35 & 0,00 & 132 \\
\hline 13 & Львівська & 1461 & 1846 & 1867 & 5,79 & 7,33 & 7,41 & 34 & 46 & 48 & 2,33 & 2,49 & 2,57 \\
\hline 14 & Миколаївська & 496 & 370 & 405 & 4,23 & 3,17 & 3,48 & 1 & 1 & 1 & 0,20 & 0,27 & 0,25 \\
\hline 15 & Одеська & 1547 & 1715 & 1739 & 6,49 & 7,19 & 7,29 & 27 & 35 & 37 & 1,75 & 2,04 & 2,13 \\
\hline 16 & Полтавська & 708 & 664 & 783 & 4,85 & 4,58 & 5,43 & 0 & 3 & 10 & 0,00 & 0,45 & 1,28 \\
\hline 17 & Рівненська & 387 & 396 & 591 & 3,35 & 3,42 & 5,09 & 9 & 8 & 11 & 2,33 & 2,02 & 1,86 \\
\hline 18 & Сумська & 57 & 55 & 48 & 0,50 & 0,49 & 0,43 & 0 & 0 & 1 & 0,00 & 0,00 & 1348 \\
\hline 19 & Тернопільська & 817 & 938 & 1103 & 7,61 & 8,77 & 10,34 & 6 & 10 & 11 & 0,73 & 1,07 & 1,00 \\
\hline 20 & Харківська & 398 & 337 & 477 & 1,46 & 1,24 & 1,76 & 2 & 6 & 12 & 0,50 & 1,78 & 2,52 \\
\hline 21 & Херсонська & 1198 & 1074 & 1101 & 11,13 & 10,03 & 10,32 & 16 & 4 & 4 & 1,34 & 0,37 & 0,36 \\
\hline 22 & Хмельницька & 835 & 1129 & 1314 & 6,37 & 8,66 & 10,12 & 33 & 14 & 18 & 3,95 & 1,24 & 1,37 \\
\hline 23 & Черкаська & 923 & 1053 & 1044 & 7,29 & 8,38 & 8,36 & 17 & 16 & 14 & 1,84 & 1,52 & 1,34 \\
\hline 24 & Чернівецька & 11 & 11 & 74 & 0,12 & 0,12 & 0,82 & 0 & 1 & 0 & 0,00 & 1311 & 0,00 \\
\hline 25 & Чернігівська & 671 & 500 & 751 & 6,28 & 4,72 & 7,17 & 12 & 13 & 26 & 1,79 & 2,60 & 3,46 \\
\hline 26 & м. Київ & 5753 & 6340 & 7486 & 20,52 & 22,42 & 26,30 & 96 & 84 & 114 & 1,67 & 1,32 & 1,52 \\
\hline
\end{tabular}

Таблиця 4. Оперативні втручання з приводу стентування коронарних артерій, проведені в регіонах України за період 2013-2015 рр.

\begin{tabular}{|c|c|c|c|c|c|c|c|c|c|}
\hline \multirow{2}{*}{$\begin{array}{l}\text { № } \\
3 / \text { ח }\end{array}$} & \multirow{2}{*}{ Регіон } & \multicolumn{3}{|c|}{$\begin{array}{c}\text { Загальна кількість } \\
\text { операцій }\end{array}$} & \multirow{2}{*}{$\begin{array}{l}\text { Показник } \\
\text { наочності }\end{array}$} & \multicolumn{3}{|c|}{ На 10 тис. всього населення } & \multirow{2}{*}{$\begin{array}{l}\text { Показник } \\
\text { наочності }\end{array}$} \\
\hline & & 2013 & 2014 & 2015 & & 2013 & 2014 & 2015 & \\
\hline 1 & $\begin{array}{l}\text { Автономна } \\
\text { Республіка Крим }\end{array}$ & 3 & 0 & 0 & 0 & 0,02 & 0,00 & 0,00 & 0 \\
\hline 2 & Вінницька & 292 & 379 & 437 & 149,7 & 1,80 & 2,35 & 2,73 & 151,7 \\
\hline 3 & Волинська & 80 & 158 & 230 & 287,5 & 0,77 & 1,52 & 2,21 & 287,0 \\
\hline 4 & Дніпропетровська & 683 & 511 & 510 & 74,7 & 2,07 & 1,55 & 1,56 & 75,4 \\
\hline 5 & Донецька & 452 & 0 & 0 & 0,0 & 1,04 & 0,00 & 0,00 & 0,0 \\
\hline 6 & Житомирська & 58 & 83 & 70 & 120,7 & 0,46 & 0,66 & 0,56 & 121,7 \\
\hline 7 & Закарпатська & 0 & 0 & 549 & - & 0,00 & 0,00 & 4,37 & - \\
\hline 8 & Запорізька & 230 & 184 & 127 & 55,2 & 1,29 & 1,04 & 0,72 & 55,8 \\
\hline 9 & Івано-Франківська & 315 & 366 & 335 & 106,3 & 2,28 & 2,65 & 2,43 & 106,6 \\
\hline 10 & Київська & 106 & 192 & 222 & 209,4 & 0,62 & 1,12 & 1,29 & 208,1 \\
\hline 11 & Кіровоградська & 83 & 97 & 107 & 128,9 & 0,84 & 0,99 & 1,10 & 131,0 \\
\hline 12 & Луганська & 432 & 0 & 0 & 0,0 & 1,92 & 0,00 & 0,00 & 0,0 \\
\hline 13 & Львівська & 390 & 605 & 609 & 156,2 & 1,55 & 2,40 & 2,42 & 156,1 \\
\hline
\end{tabular}


Продовження табл. 4

\begin{tabular}{|c|c|c|c|c|c|c|c|c|c|}
\hline \multirow{2}{*}{$\begin{array}{l}\text { № } \\
\text { 3/ח }\end{array}$} & \multirow{2}{*}{ Регіон } & \multicolumn{3}{|c|}{$\begin{array}{c}\text { Загальна кількість } \\
\text { операцій }\end{array}$} & \multirow{2}{*}{$\begin{array}{l}\text { Показник } \\
\text { наочності }\end{array}$} & \multicolumn{3}{|c|}{ На 10 тис. всього населення } & \multirow{2}{*}{$\begin{array}{l}\text { Показник } \\
\text { наочності }\end{array}$} \\
\hline & & 2013 & 2014 & 2015 & & 2013 & 2014 & 2015 & \\
\hline 14 & Миколаївська & 306 & 209 & 265 & 86,6 & 2,61 & 1,79 & 2,28 & 87,4 \\
\hline 15 & Одеська & 326 & 324 & 357 & 109,5 & 1,37 & 1,36 & 1,50 & 109,5 \\
\hline 16 & Полтавська & 101 & 107 & 169 & 167,3 & 0,69 & 0,74 & 1,17 & 169,6 \\
\hline 17 & Рівненська & 256 & 289 & 434 & 169,5 & 2,21 & 2,50 & 3,74 & 169,2 \\
\hline 18 & Сумська & 0 & 0 & 0 & 0 & 0,00 & 0,00 & 0,00 & 0 \\
\hline 19 & Тернопільська & 189 & 214 & 265 & 140,2 & 1,76 & 2,00 & 2,48 & 140,9 \\
\hline 20 & Харківська & 160 & 205 & 315 & 196,9 & 0,59 & 0,75 & 1,16 & 196,6 \\
\hline 21 & Херсонська & 214 & 203 & 200 & 93,5 & 1,99 & 1,90 & 1,88 & 94,5 \\
\hline 22 & Хмельницька & 393 & 668 & 376 & 95,7 & 3,00 & 5,12 & 2,90 & 96,7 \\
\hline 23 & Черкаська & 503 & 503 & 579 & 115,1 & 3,98 & 4,00 & 4,64 & 116,6 \\
\hline 24 & Чернівецька & 0 & 0 & 67 & - & 0,00 & 0,00 & 0,74 & - \\
\hline 25 & Чернігівська & 214 & 140 & 274 & 128,0 & 2,00 & 1,32 & 2,62 & 131,0 \\
\hline 26 & м. Київ & 1031 & 1364 & 1886 & 182,9 & 3,68 & 4,82 & 6,63 & 180,2 \\
\hline
\end{tabular}

Таблиця 5. Післяопераційна летальність після проведених операцій стентування коронарних артерій у регіонах Україні за період 2013-2015 рр.

\begin{tabular}{|c|c|c|c|c|c|c|c|c|}
\hline \multirow{2}{*}{$\begin{array}{l}\text { № } \\
3 / \Pi\end{array}$} & \multirow[t]{2}{*}{ Регіон } & \multicolumn{3}{|c|}{$\begin{array}{c}\text { Кількість померлих у результаті } \\
\text { операцій }\end{array}$} & \multicolumn{3}{|c|}{$\begin{array}{c}\text { Післяопераційна летальність } \\
\text { (\%) }\end{array}$} & \multirow{2}{*}{ Темп росту } \\
\hline & & 2013 & 2014 & 2015 & 2013 & 2014 & 2015 & \\
\hline 1 & $\begin{array}{l}\text { Автономна } \\
\text { Республіка Крим }\end{array}$ & 0 & 0 & 0 & 0,00 & 0,00 & 0,00 & 0 \\
\hline 2 & Вінницька & 2 & 9 & 11 & 0,68 & 2,37 & 2,52 & $370,6^{*}$ \\
\hline 3 & Волинська & 1 & 0 & 1 & 1,25 & 0,00 & 0,43 & $34,4^{*}$ \\
\hline 4 & Дніпропетровська & 5 & 7 & 11 & 0,73 & 1,37 & 2,16 & $295,9^{*}$ \\
\hline 5 & Донецька & 7 & 0 & 0 & 1,55 & 0,00 & 0,00 & 0,0 \\
\hline 6 & Житомирська & 0 & 1 & 1 & 0,00 & 1,20 & 1,43 & $119,2^{\star \star}$ \\
\hline 7 & Закарпатська & 0 & 0 & 11 & 0,00 & 0,00 & 2,00 & - \\
\hline 8 & Запорізька & 1 & 5 & 0 & 0,43 & 2,72 & 0,00 & 0,0 \\
\hline 9 & Івано-Франківська & 0 & 9 & 13 & 0,00 & 2,46 & 3,88 & $157,7^{\star \star}$ \\
\hline 10 & Київська & 4 & 1 & 2 & 3,77 & 0,52 & 0,90 & $23,9^{*}$ \\
\hline 11 & Кіровоградська & 1 & 0 & 5 & 1,20 & 0,00 & 4,67 & $389,2^{*}$ \\
\hline 12 & Луганська & 4 & 0 & 0 & 0,93 & 0,00 & 0,00 & 0,0 \\
\hline 13 & Львівська & 0 & 8 & 3 & 0,00 & 1,32 & 0,49 & $37,1^{\text {** }}$ \\
\hline 14 & Миколаївська & 0 & 0 & 0 & 0,00 & 0,00 & 0,00 & 0 \\
\hline 15 & Одеська & 4 & 12 & 20 & 1,23 & 3,70 & 5,60 & $455,3^{*}$ \\
\hline 16 & Полтавська & 0 & 1 & 6 & 0,00 & 0,93 & 3,55 & $381,7^{* *}$ \\
\hline 17 & Рівненська & 3 & 5 & 8 & 1,17 & 1,73 & 1,84 & $157,3^{\star}$ \\
\hline 18 & Сумська & 0 & 0 & 0 & 0,00 & 0,00 & 0,00 & 0 \\
\hline 19 & Тернопільська & 1 & 3 & 3 & 0,53 & 1,40 & 1,13 & $213,2^{*}$ \\
\hline 20 & Харківська & 0 & 3 & 9 & 0,00 & 1,46 & 2,86 & $195,9^{\star \star}$ \\
\hline 21 & Херсонська & 0 & 0 & 0 & 0,00 & 0,00 & 0,00 & 0 \\
\hline 22 & Хмельницька & 13 & 7 & 7 & 3,31 & 1,05 & 1,86 & $56,2^{*}$ \\
\hline 23 & Черкаська & 8 & 6 & 8 & 1,59 & 1,19 & 1,38 & $86,8^{*}$ \\
\hline 24 & Чернівецька & 0 & 0 & 0 & 0,00 & 0,00 & 0,00 & 0 \\
\hline 25 & Чернігівська & 5 & 2 & 11 & 2,34 & 1,43 & 4,01 & $171,4^{*}$ \\
\hline 26 & М. Київ & 0 & 2 & 9 & 0,00 & 0,15 & 0,48 & 320,0 ** \\
\hline
\end{tabular}

Примітка: * - темп росту розраховували порівняно із 2013 р.;

** - темп росту розраховували порівняно з 2014 р. 
Отримані дані свідчать про істотне зростання як рівня оперативних втручань з приводу СКА за досліджуваний період на 28,1\%, так і його частки серед усіх операцій на серці. Найвищий рівень оперативних втручань з приводу СКА спостерігався у 2015 р. у м. Києві, Черкаській, Закарпатській та Рівненській областях. Найнижчий - у Житомирській, Чернівецькій та Запорізькій областях.

Найбільше зростання післяопераційної летальності у 2015 р. порівняно із 2013-2014 рр. спостерігалося в Одеській, Кіровоградській та Полтавській областях. Деяке зменшення післяопераційної летальності відмічалося у Київській, Волинській, Львівській областях.

\section{Висновки}

За період 2013-2015 рр. в Україні відбулося активне впровадження інтервенційного методу лікування пацієнтів з інфрарктом міокарда та нестабільною стенокардією.

Перспективи подальших досліджень полягають у вивченні рівня оперативних втручань з приводу СКА в окремих районах та їх порівняння із захворюваністю на ішемічну хворобу серця.

\section{Список літератури}

1. Беш Д. І. Вплив стентування коронарних артерій на перебіг ішемічної хвороби серця у пацієнтів 3 інфрарктом міокарда в анамнезі [Електронний ресурс] / Д. І. Беш // Патологія. - 2010. - Т. 7, № 3. - С. 17-20. - Режим доступу : http://nbuv.gov.ua/UJRN/pathology_2010_7_3_5

2. Віддалені результати перкутанної реканалізації хронічних оклюзій коронарних артерій / Ю. Н. Соколов, М. Ю. Соколов, А. В. Циж, Н. Ю. Чубко // Серце і судини. - 2006. - № 1 (13). - С. 34-40.

3. Кудря І. П. Оцінка перебігу та якості життя у хворих на ішемічну хворобу серця після стентування коронарних артерій / І. П. Кудря, Т. І. Шевченко // Актуальні проблеми сучасної медицини. - 2014. - Т. 14, Вип. 2. - С. 19-22.

4. Показники здоров'я населення та використання ресурсів охорони здоров'я в Україні за 2013 рік: довідник / МОЗ України, Центр медичної статистики. - Київ, 2014. - 327 с.

5. Показники здоров'я населення та використання ресурсів охорони здоров'я в Україні за 2014 рік : довідник I МОЗ України, Центр медичної статистики. - Київ, 2015. - 316 с.

6. Показники здоров'я населення та використання ресурсів охорони здоров'я в Україні за 2015 рік : довідник / МОЗ України, Центр медичної статистики. - Київ, 2016. - 285 с.

7. Результати ангіопластики та первинного стентування коронарних артерій у хворих з нестабільною стенокардією / Ю. В. Панічкін, Є. В. Аксьонов, В. С. Берестовенко, Л. С. Дзахоєва // Серце і судини. - 2006. - № 3 (15). - С. $41-45$. 8. Савченко А. П. Интервенционная кардиология. Коронарная ангиограсрия и стентирование : руководство / А. П. Савченко, О. В. Черкавская, Б. А. Руденко. - Москва : ГЭОТАР-Медиа, 2010. - 448 с.

9. Система оцінки деформацій коронарних артерій при стентуванні або аортокоронарному шунтуванні [Електронний ресурс] / Г. В. Книшов, Є. А. Настенко, А. О. Матвійчук [та ін.] // Системні дослідження та інформаційні технології. 2014. - № 3. - С. 17-24. - Режим доступу: http://nbuv.gov.ua/UJRN/sdtit_2014_3_4. - Назва з екрану.

\section{References}

1. Besh, D.I. (2010). Vplyv stentuvannya koronarnykh arteriy na perebih ishemichnoi khvoroby sertsya u patsiyentiv z infarktom miokarda $v$ anamnezi [Effect of coronary stenting on the course of ischemic heart disease in patients with myocardial infarction in the anamnesis]. Patolohiya - Pathologia, 7 (3), 17-20 Retrieved from http://nbuv.gov.ua/UJRN/ pathology_2010_7_3_5[in Ukrainian].

2. Sokolov, Yu.N., Sokolov, M.Yu., Tsyzh, A.V. \& Chubko N.Yu. (2006). Viddaleni rezultaty perkutannoyi rekanalizatsii khronichnykh oklyuziy koronarnykh arteriy [Long-term results of percutaneous recanalization of chronic coronary artery occlusions]. Sertse i sudyny - Heart and Vessels, 1 (13), 34-40 [in Ukrainian].

3. Kudrya, I.P. \& Shevchenko, T.I. (2014). Otsinka perebihu ta yakosti zhyttya u khvorykh na ishemichnu khvorobu sertsya pislya stentuvannya koronarnykh arteriy [Evaluation of clinical course and quality of life in patients with coronary heart disease after coronary artery stenting]. Aktualni problemy suchasnoi medytsyny-Actual Problems of the Modern Medicine, 14 (2), 19-22 [in Ukrainian].

4. Pokaznyky zdorovya naselennya ta vykorystannya resursiv okhorony zdorovya v Ukraini za 2013 rik: dovidnyk [Indices of health and the use of health resources in Ukraine for 2013: reference book]. (2014). Kyiv: MOZ Ukrainy, Tsentr medychnoi statystyky [in Ukrainian].

5. Pokaznyky zdorovya naselennya ta vykorystannya resursiv okhorony zdorovya v Ukraini za 2014 rik: dovidnyk [Indices of health and the use of health resources in Ukraine for 2014: reference book]. (2015). Kyiv: MOZ Ukrainy, Tsentr medychnoi statystyky [in Ukrainian].

6. Pokaznyky zdorovya naselennya ta vykorystannya resursiv okhorony zdorov'ya v Ukrayini za 2015 rik : dovidnyk [Indices of health and the use of health resources in Ukraine for 2015: reference book]. (2016). Kyiv: MOZ Ukrayiny, Tsentr medychnoyi statystyky [in Ukrainian].

7. Panichkin, Yu.V, Aksionov, Ye.V., Berestovenko, V.S. \& Dzakhoeva, L.S. (2006). Rezultaty anhioplastyky ta pervynnoho stentuvannya koronarnykh arteriy u khvorykh z nestabilnoyu stenokardiyeyu [The results of angioplasty and primary stenting of coronary arteries in patients with unstable stenocardia]. Sertse i sudyny - Heart and Vessels, 3 (15), $41-45$ [in Ukrainian].

8. Savchenko, A.P., Cherkavskaya, O.V. \& Rudenko, B.A. (2010). Interventsyonnaya kardyologiya. Koronarnaya angiografiya $i$ stentirovanye [Interventional cardiology. Coronary angiography and stenting]. Moskva: HÉOTAR-Medya [in Russian]. 
9. Knyshov, H.V., Nastenko, E.A., Matviichuk, A.O., Salo, S.V., Lebedeva, E.A., Kiseleva, O.H. et al. (2014). Systema otsinky deformatsiy koronarnykh arteriy pry stentuvanni abo aortokoronarnomu shuntuvanni [Evaluation system under strain coronary artery stenting or bypass bypass surgery]. Systemni doslidzhennya ta informatsiyni tekhnolohii - System Research and Information Technologies, 3, 17-24 Retrieved from http://nbuv.gov.ua/UJRN/sdtit_2014_3_4 [in Ukrainian].

\section{ВНЕДРЕНИЕ МЕТОДА СТЕНТИРОВАНИЯ КОРОНАРНЫХ АРТЕРИЙ В УКРАИНЕ}

Н.А. Теренда

ГВУЗ «Тернопольский государственный медицинский университет имени И.Я. Горбачевского МЗ Украины»,

г. Тернополь, Украина

Цель - анализ внедрения метода стентирования коронарных артерий (СКА) в лечении пациентов с ишемической болезнью сердца в Украине и ее областях.

Материалы и методы. Материалом исследования послужили данные ГУ «Центр медицинской статистики МЗ Украины» о количестве оперативных вмешательств на сердце и проведенных операций СКА в Украине. В работе использованы метод системного анализа и статистический метод исследования.

Результаты. Полученные данные свидетельствуют о существенном росте как уровня оперативных вмешательств по поводу СКА за период 2013-2015 гг. на 28,1\%, так и его доли среди всех операций на сердце. Самый высокий уровень оперативных вмешательств по поводу СКА в 2015 г. наблюдался в г. Киеве, Черкасской, Закарпатской и Ровенской областях. Самый низкий - в Житомирской, Черновицкой и Запорожской областях. Наибольший рост послеоперационной летальности в 2015 г. по сравнению с 2013-2014 гг. наблюдался в Одесской, Кировоградской и Полтавской областях. Некоторое уменьшение послеоперационной летальности отмечалось в Киевской, Волынской, Львовской областях.

Выводы. За период 2013-2015 гг. в Украине произошло активное внедрение интервенционного метода лечения пациентов с инфарктом миокарда и нестабильной стенокардией.

КЛЮЧЕВЫЕ СЛОВА: стентирование коронарных артерий, операции на сердце, инфаркт миокарда, уровень оперативных вмешательств, послеоперационная летальность.

\section{INTRODUCTION OF THE METHOD OF CORONARY ARTERY STENTING IN UKRAINE}

N.O. Terenda

I. Horbachevsky Ternopil State Medical University

The aim of our research is to analyze the introduction of the method of coronary artery stenting (CAS) in patients with coronary heart disease in Ukraine and its regions.

Materials and methods. The data of the SC «Center for Health Statistics of the Ministry of Health of Ukraine» on the number of heart surgeries and CAS operations in Ukraine was used for the research. We used the methods of system analysis and statistical research.

Results. The data show a significant increase in CAS surgery in 2013-2015. 28.1\%, and its share of all heart surgery. In 2015, the highest level of surgical interventions for CAS was observed in the city of Kiev, in Cherkasy, Transcarpathian and Rivne regions. The lowest - in Zhytomyr, Chernivtsi and Zaporizhia regions.

In 2015, the largest increase in postoperative mortality compared to 2013-2014 was observed in Odessa, Kirovograd and Poltava regions. Some decrease in postoperative mortality was noted in Kyiv, Volyn, and Lviv regions.

Conclusions. During the period of 2013-2015, Ukraine saw active introduction of interventional treatment of myocardial infarction and unstable angina patients.

KEY WORDS: coronary artery stenting, heart surgery, heart attack, level of surgical interventions, postoperative mortality.

Рукопис надійшов до редакції: 12.12.2016 p.

Відомості про автора:

Теренда Наталія Олександрівна - к.мед.н., доцент кафедри соціальної медицини, організації та економіки охорони здоров'я з медичною статистикою ДВНЗ «Тернопільський державний медичний університет імені І.Я. Горбачевського МОЗ України»; тел.: +38(0352)-52-72-33. 